\title{
Thermodynamic Studies of the Removal of Lead from Synthetic Wastewater using Cyperus rotundus (Nut grass)
}

\author{
DAVOUD BALARAK ${ }^{1}$, HADISE MARDANSHAHI², \\ KETHINENI CHANDRIKA ${ }^{3 *}$ and C. S. FELICE ${ }^{4}$ \\ 'Department of Environmental Health, Health Promotion Research Center, \\ Zahedan University of Medical Sciences, Zahedan, Iran. \\ ${ }^{2}$ Student Research Committee, Zahedan University of Medical Sciences, Zahedan, Iran. \\ ${ }^{3}$ Department of Petroleum Engineering, KoneruLakshmaiah Education Foundation, \\ Vaddeswaram, Guntur, AP, India-52250. \\ ${ }^{4}$ Department of Biotechnology, KoneruLakshmaiah Education Foundation, \\ Vaddeswaram, Guntur, AP, India-52250. \\ ${ }^{*}$ Corresponding Author: kkchandrika@ kluniversity.in \\ http://dx.doi.org/10.13005/ojc/350508 \\ (Received: September 01, 2019; Accepted: October 06, 2019)

\begin{abstract}
This research was accomplished to appraise the performance of Cyperus rotundus (Nut grass) Stalk (CRS) in adsorption of lead, heavy metal of aquatic environments. For this purpose, the batch system was used to review the effect $\mathrm{pH}$, mixing time, adsorbent particle size and temperature for $\mathrm{Pb}$ (II) removal by the $\mathrm{CRS}$. The highest lead removal efficacy was achieved when $\mathrm{pH}$ is 6 and it was considered as the optimum $\mathrm{pH}$. The result indicated the maximum $\mathrm{Pb}(\mathrm{II})$ adsorption at the contact time of $90 \mathrm{~min}$ which implies that increase in contact time leads to a higher lead uptake. The amount of R2 statistical parameter using the pseudo-second-order is greater as compared with other models. The influence of temperature was determined by using thermodynamic parameters and the results showed removal of lead on the CRS was endothermic, spontaneous and feasible.
\end{abstract}

Keywords: Pb(II), Cyperus Rotundus, Thermodynamics, Kinetics, Synthetic Wastewater.

\section{INTRODUCTION}

Heavy metals are most important pollutants and its presence in wastewaters can be the striking environmental issue, after all, dissolved toxic metal ions can finally enter the food chain and thus become for human health is a risk factor ${ }^{1,2}$.
A number of industries, such as metalworking, mining and leather tanning, have a significant role in releasing of the heavy metals into the effluents; this event concludes to the freshwater pollution and receiving waters ${ }^{3}$. Heavy metals are not biodegradable and can accumulate in tissues and can create different diseases and disorders ${ }^{4}$.

This is an Open Access article licensed under a Creative Commons license: Attribution 4.0 International (CC- BY). Published by Oriental Scientific Publishing Company @ 2018 
One of such heavy metal of concern is $\mathrm{Pb}(\mathrm{II})$ which the inadvertent exposure and consumption of the water and food contaminated by this element for extended periods, even with its low concentration, can bring an extensive range of health issues, e.g., cancer, convulsions, nausea, subtle effects on metabolism and intelligence, renal failure, nausea, coma ${ }^{5,6}$. Over the years, more than a few methods have progressed to remove the lead existed in effluent ${ }^{7}$. At higher concentrations, lead impairs cognitive development, and introduced as an enzyme inhibitor in the body, because it can replace the vital element zinc from heme enzymes ${ }^{8}$. The highest allowable limit of $\mathrm{Pb}$ (II) in potable water which is publicized by the World Health Organization is $50 \mu \mathrm{g} / \mathrm{L}$, while the United States Environmental Protection Agency has approved the values lesser than $15 \mu \mathrm{g} / \mathrm{L}$ as the safe limit in this case ${ }^{9}$. The above-mentioned effects of the lead demonstrate the obligation of removing these elements from waters and wastewaters to enhance the protection of public health and environment ${ }^{10}$.

Although, there are various methods to eradicate the heavy metal such as adsorption, reverse osmosis, filtration, ion exchange, electrochemical and precipitation ${ }^{1}$; however, nearly all of them have not an adequate performance comparing to their operational cost ${ }^{12}$. Precipitation methods have found to be an authentic method but they need to large settling tanks and a subsequent treatment which it is led to diminishing the applicability of this method ${ }^{13,14}$. Ion exchange is another method in field of the removing the heavy metal, which allows the extraction of metal ions, but it is an expensive and complex method ${ }^{15}$.

Adsorption has classified as an economically sensible substitute technique to remove the lead. Different materials as absorbent have been applied for remove heavy metal from solutions such as Azolla filiculoides, canola, Lemna minor, corn husk ash, Orange peel, and banana ${ }^{16-19}$. Nowadays, this type of material is increasingly attracting attention to be used to remove heavy metals.

Cyperus rotundus (Nut grass) has recognized as one of the most invasive weeds which it can extensively observe in tropical and temperate regions ${ }^{20}$. It can be found in more than 90 countries and can infest more than 50 crops; hence, it is called as the world's worst weed ${ }^{21}$. Therefore, CRS was applied for decrease lead as an important contaminant from an aquatic environment at adsorption process. The effect of influential parameters at batch adsorption process such as mixing time, CRS particle size, temperature and $\mathrm{pH}$ was investigated.

\section{EXPERIMENTAL}

\section{Preparation of Adsorbent}

The Cyperus rotundus (Nut grass) Stalk was gathered from agricultural university of Tabriz. The CRS was first washed carefully with deionized water. Then, they rinsed with the hot deionized water $\left(75^{\circ} \mathrm{C}\right)$ were used to remove the soluble colored. The dried biomass sample was exposed at $0.5 \mathrm{M} \mathrm{HCL}$ solution for 120 min under slow stirring. The CRS was dried at $75^{\circ} \mathrm{C}$ at 24 hours. The dried CRS were chopped and sifted at 10 to 100 mesh and stored in polythene bottles.

\section{Preparation of $\mathrm{Pb}$ (II)solution}

A stock solution of lead (concentration of $1000 \mathrm{ppm}$ ) was provided using an accurately weighed quantity of the $\mathrm{Pb}\left(\mathrm{NO}_{3}\right)_{2}$ in double-distilled water. Various concentration of lead solution provided with diluted the stock solution. $0.1 \mathrm{~N}$ $\mathrm{NaOH}$ and $\mathrm{HCL}$ were used to adapt the $\mathrm{pH}$ values of metal solutions.

\section{Batch adsorption experiments}

All chemicals used were provided by Merck \& Co. (USA). These chemicals are analytical reagents and used without further purification. All solutions were provided by the double-distilled water. To conduct a batch experiment, $0.1 \mathrm{~L}$ of lead solution (concentrations of 10-200 ppm) were poured into a container $(200 \mathrm{ml})$, then $2.5 \mathrm{~g} / \mathrm{L}$ or $0.25 \mathrm{~g} / 100 \mathrm{ml}$ of CRS was added to the solution containing lead. Finally, the prepared mixture is stirred for $1.5 \mathrm{~h}$ at $150 \mathrm{rpm}$ on a mechanical shaker and passed $0.45 \mu \mathrm{m}$ nitrocellulose membrane. To measure the lead solution, the AAS (Atomic Absorption Spectrophotometer) was utilized. The experiments in present study were repeated 3 times and the average of these three-step experiments was presented as the results. It should be noted that the control experiments were performed using the blanks containing no metal ions. 
The below equations are applied to determine the \%removal and amount adsorbed $(\mathrm{mg} / \mathrm{g})$ of lead. $22-24$

$\mathrm{q}_{\mathrm{e}}=\frac{\left(\mathrm{C}_{0}-\mathrm{C}_{\mathrm{e}}\right) \times \mathrm{V}}{\mathrm{W}}$

$\mathrm{C}_{0}$ istheleadconcentrationatan initial solution $(\mathrm{mg} / \mathrm{L}), \mathrm{C}_{\mathrm{e}}$ is the concentration of lead in effluent after removal $(\mathrm{mg} / \mathrm{L}), \mathrm{V}$ is the amount of the solution $(\mathrm{L})$ and $\mathrm{W}$ is the weight $(\mathrm{g})$ of the CRS applied.

\section{RESULTS AND DISCUSSION}

\section{Effect of CRS Particle Size the Adsorption of lead}

Figure 1 epitomizes the lead removal by CRS at different adsorbent particles size. This Fig indicates that the increase in particle size is led to reducing the adsorption capacity. The highest lead adsorption of CRS recorded was $71.60 \mathrm{mg} / \mathrm{g}$ which it was related to a particle size of 100 mesh. This event observed in this part of the study can be elucidated by the topic that the fine size of the CRS particles has the greater interior surface area and the micro-pore amount which it can be concluded to more active sites for adsorption..$^{25-27}$ But, for higher particles, the pore diffusion resistance is greater for mass transfer, which it can decrease and can eliminate the utilization of the internal surfaces of the particle in adsorption of the $\mathrm{Pb}(\mathrm{II})$ and it can consequently decrease the amount of $\mathrm{Pb}$ (II) adsorbed. ${ }^{28,29}$

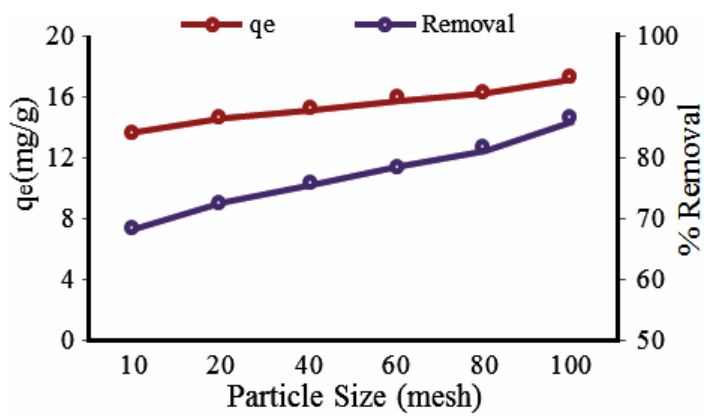

Fig. 1. Effect of adsorbent particle size (PH: 6, CRS dosage: $2.5 \mathrm{~g} / \mathrm{L}, \mathrm{C}_{0}: 50 \mathrm{ppm}$, mixing time: $120 \mathrm{~min}$ and $\mathrm{T}: 25^{\circ} \mathrm{C}$ )

\section{Effect of PH on Lead Removal}

The $\mathrm{pH}$ has identified as a very important parameter that can significantly affect the biosorption process. The optimization of $\mathrm{pH}$ in the present study was performed at the $\mathrm{pH}$ between of 2.0-8.0. The data obtained from this section is presented in Fig. 2. As it can be observed, The $\mathrm{Pb}$ (II) removal is absolutely dependent upon the $\mathrm{pH}$ up to 6.0 and it remains practically constant after this $\mathrm{pH}$ value, and the \%removal was $89.9 \%$ at this $\mathrm{pH}$. The competition raised between the lead ions and $\mathrm{H}^{+}$ions which it exists on the binding sites of the cells is the reason for decreasing the adsorption capacity at lower $\mathrm{pH}^{30,31}$.

\section{Determination of thermodynamic parameters}

The effect of the temperature was evaluated at various temperatures $(25,35,45$ and $55^{\circ} \mathrm{C}$ ) and the data obtained of this section were presented in Fig. 3. The higher temperature assists to advance the removal of lead on CRS (i. e. endothermic process). Furthermore, it may produce an inflation effect within the internal part of the biosorbent which it can help to penetrate more $\mathrm{Pb}$ (II) ions. ${ }^{32,33}$

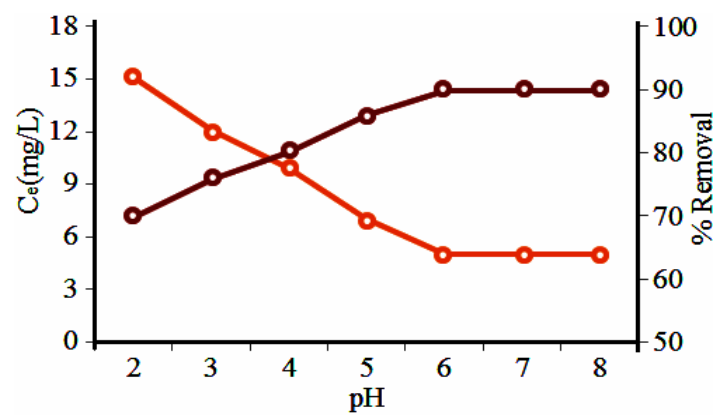

Fig. 2. Effect of pH (CRS dosage: $2.5 \mathrm{~g} / \mathrm{L}, \mathrm{C}_{0}: 50 \mathrm{ppm}$, mixing time: $120 \mathrm{~min}$ and $\mathrm{T}: 25^{\circ} \mathrm{C}$ )

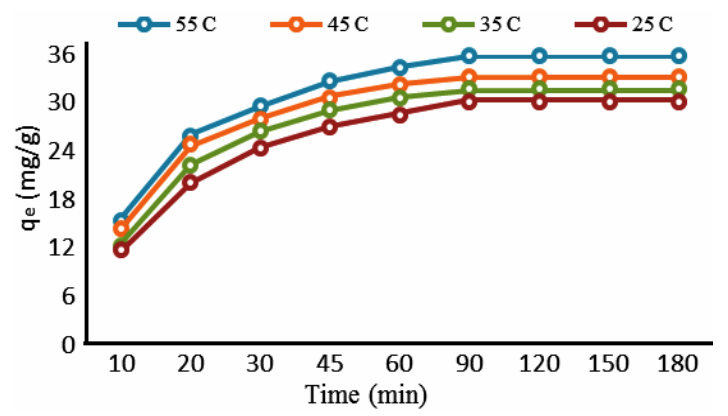

Fig. 3. Effect of temperature (PH: 6, CRS dosage: $2.5 \mathrm{~g} / \mathrm{L}$, $\left.\mathrm{C}_{0}: 100 \mathrm{ppm}\right)$

Thermodynamic parameters, i.e., free energy change $\left(\Delta G^{\circ}\right)$, enthalpy change $\left(\Delta H^{\circ}\right)$, and entropy change $\left(\Delta S^{\circ}\right)$ is utilized to determine whether the adsorption process is spontaneous or not. $\Delta \mathrm{G}^{\circ}$ is determined by the below equation. ${ }^{34-36}$

$\Delta G^{\circ}=-R T L n K$

$R$ and $T$ are the universal gas constant and temperature, and $\mathrm{K}$ is the distribution coefficient. 
The following equation expresses the relation between $\Delta \mathrm{G}^{\circ}, \Delta \mathrm{H}^{\circ}$ and $\Delta \mathrm{S}^{\circ} .{ }^{37,38}$

$\Delta \mathrm{G}^{\circ}=\Delta \mathrm{H}^{\circ}-\mathrm{T} \Delta \mathrm{S}^{\circ}$

$\operatorname{Ln} \mathrm{K}=\frac{\Delta S^{0}}{R}-\frac{\Delta H^{0}}{R T}$

The amount of $\Delta \mathrm{G}^{\circ}, \Delta \mathrm{H}^{\circ}$, and $\Delta \mathrm{S}^{\circ}$ related to the removal of lead on the CRS at various temperatures as shown in Table 1. A negative amount of $\Delta G^{\circ}$ obtained shows the possibility of the adsorption process. The positive amount of $\Delta \mathrm{H}^{\circ}$ proves the endothermic nature of adsorption. The positive amount of $\Delta S^{\circ}$ implies increase randomness at the solid/solution interface during the removal lead on the CRS.

Table 1: Thermodynamic data for lead removal onto CRS at various temperatures

\begin{tabular}{cccc}
\hline $\mathrm{T}\left({ }^{\circ} \mathrm{C}\right)$ & $\Delta \mathrm{G}^{\circ}(\mathrm{kJ} / \mathrm{mol})$ & $\Delta \mathrm{S}^{\circ}(\mathrm{J} / \mathrm{mol} \mathrm{K})$ & $\Delta \mathrm{H}^{\circ}(\mathrm{kJ} / \mathrm{mol})$ \\
\hline 25 & -1.044 & 34.48 & 7.291 \\
35 & -1.95 & & \\
45 & -2.36 & & \\
55 & -2.87 & & \\
\hline
\end{tabular}

\section{Effect of Adsorbent Dose}

The effect of CRS dosage on the removal of lead was applied by changes the mass of CRS in the value $0.5-4 \mathrm{~g} / \mathrm{L}$ (Fig. 4). The adsorption capacity leaned to decrease with the increase of CRS amount. At the higher dose of adsorbent, the adsorbent may aggregate which it can reduce the number of the binding site and consequently, the adsorption capacities ${ }^{39}$.

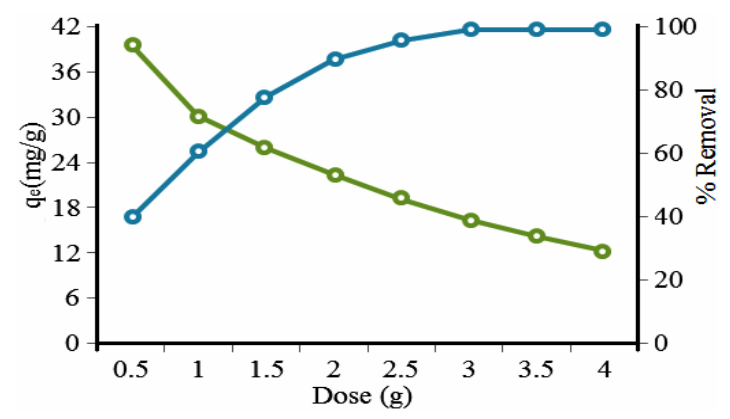

Fig. 4. Effect of CRS dosage (pH: 6, $\mathrm{C}_{0}: 50 \mathrm{ppm}$, mixing time: $120 \mathrm{~min}$ and $\mathrm{T}: 25^{\circ} \mathrm{C}$ )

\section{Kinetic models}

Kinetic studies are important for any type of adsorption process. For the adsorption model, Pseudo-first-order (PFO) and pseudo-second-order (PSO) kinetic and Intra-particle diffusion (IPD) can be proposed. PFO kinetics is to describe the rate of adsorption process in liquid-solid phase. The Patent foramen ovale (PFO) is represented as. ${ }^{40}$

$$
\frac{\mathrm{dq}}{\mathrm{dt}}=\mathrm{K}_{1}\left(\mathrm{q}_{\mathrm{e}}-\mathrm{q}_{\mathrm{t}}\right)
$$

The above equation after definite integration. ${ }^{41,42}$

$$
\log \left(\mathrm{q}_{\mathrm{e}}-\mathrm{q}_{\mathrm{t}}\right)=\log \mathrm{q}_{\mathrm{e}}-\frac{K_{1}}{2.303} \mathrm{t}
$$

The PSO equation can be shown following Eq. ${ }^{43,44}$

$$
\frac{\mathrm{dq}}{\mathrm{dt}}=\mathrm{K}_{2}\left(\mathrm{q}_{\mathrm{e}}-\mathrm{q}_{\mathrm{t}}\right)^{2}
$$

Where, $\mathrm{K}_{1}$ and $\mathrm{K}_{2}$ are the rate constants of the $\mathrm{PFO}$ and PSO.

The linear form of the above-mentioned Eq is. ${ }^{45}$

$$
\frac{\mathrm{t}}{\mathrm{q}}=\frac{1}{\mathrm{k}_{2} \mathrm{qe}^{2}}+\frac{\mathrm{t}}{\mathrm{qe}}
$$

The findings are given in Table 2. The amount of $R^{2}$ with PFO was less of 0.912 , while for PSO was high of 0.99 for all concentrations. It is comprehensible that the removal of lead on CRS biomass is better demonstrated by PSO which it indicates the adsorption system pertains to the PSO model.

IPD is another model that was also utilized to realize whether the rate restrictive step is the IPD, film diffusion, or mass action. Since the mass action is an extremely quick step in physical adsorption; hence it can be neglected. Weber-Moris represented the IPD model and it can be written following Eq. ${ }^{45}$

$q_{t}=K_{d} t^{1 / 2}+l$

The value of the slope correlates to Integrated project delivery (IPD) constant and the intercept value at an approximate value of the boundary layer thickness (Fig. 5). The data at three different concentrations illustrate two stages of linearity. The first stage is related to the immediate adsorption which it completed well within the initial $45 \mathrm{~min}$; the gradual adsorption is the second stage. Both the linear lines, which they are not passing through the origin, suggest that there are other limiting mechanisms in the adsorption process and the IPD is not the only limiting mechanism. Table 2 represents the $k d$ and $R^{2}$ obtained for the IPD. The values of $R^{2}$ are lower than expected values of the Pseudo second order (PSO) model which it is clarify that the qexp values are not in accordance with the IPD. 
Table 2: Kinetic data for the removal of lead on CRS biomass at various concentration

\begin{tabular}{|c|c|c|c|c|c|c|c|c|c|c|}
\hline \multirow[t]{2}{*}{$\mathrm{C}_{0}(\mathrm{mg} / \mathrm{L})$} & \multirow[t]{2}{*}{$q_{e} \exp (m g / g)$} & \multicolumn{3}{|c|}{ PFO } & \multicolumn{3}{|c|}{ PSO } & \multicolumn{3}{|c|}{ IPD } \\
\hline & & $\mathrm{K}_{1}$ & $\mathrm{q}_{\mathrm{e}} \mathrm{cal}$ & $\mathrm{R}^{2}$ & $\mathrm{~K}^{2}$ & $\mathrm{q}_{\mathrm{e}} \mathrm{cal}$ & $\mathrm{R}^{2}$ & $\mathrm{~K}_{\mathrm{d}}$ & 1 & $\mathrm{R}^{2}$ \\
\hline 50 & 14.29 & 0.0354 & 8.491 & 0.889 & 0.0824 & 11.56 & 0.998 & 0.148 & 0.849 & 0.825 \\
\hline 100 & 29.55 & 0.0485 & 21.73 & 0.912 & 0.0596 & 27.44 & 0.996 & 0.191 & 1.654 & 0.794 \\
\hline 200 & 48.18 & 0.0562 & 32.65 & 0.858 & 0.0312 & 46.39 & 0.993 & 0.236 & 1.974 & 0.841 \\
\hline
\end{tabular}

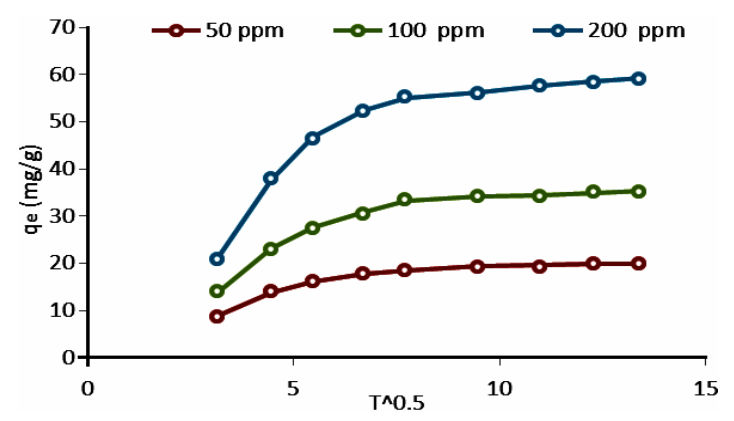

Fig. 5. IPD kinetics plot for lead removal onto CRS biomass

\section{CONCLUSION}

The results showed that the CRS biomass is a flourishing adsorbent towards the adsorption of heavy metal lead from aquatic environments. The
$\mathrm{pH}$ was found to be an effective parameter on lead removal, so that the increase of $\mathrm{pH}$ is led to develop the removal efficacy. $\mathrm{pH}=6$ was observed to be the optimum $\mathrm{pH}$. Thermodynamic studies showed that a viable and impulsive and endothermic process occurs during the removal of lead on CRS. It is also confirmed by this fact that the lead adsorption increases by temperature rise.

\section{ACKNOWLEDGMENT}

The authors are grateful to the Zahedan University of Medical Sciences for the financial support of this study.

\section{Conflicting interest}

There is no conflicting interest in this study.

\section{REFERENCES}

1. Mohan, D.; Pittman, D. C. U.; Bricka, M.; Smith, F.; Yancey, B.; Mohammad, J. P. J. Colloid. Interface. Sci., 2007, 310, 57-73.

2. Shin, E. W.; Rowell, R. M. Chemosphere., 2005, 60, 1054-1061.

3. Balarak, D.; Azarpira, H. Int. J. ChemTech. Res., 2016, 9(9), 543-549.

4. Balarak, D.; Joghataei, A.; Azarpira, H.; Mostafapour, F. K. Int. J. Pharm. Technol., 2016, 8(3), 15780-88.

5. Bulut, Y.; Tez, Z. J. Hazard. Mater., 2007, 149, 35-41.

6. Axtell, N. R.; Sternberg, S. P. K.; Claussen, K. Bioresour. Technol., 2003, 89, 41-48.

7. Amarasinghe, W. P. K.; Williams, R. A. J. Chem. Eng., 2007, 32, 299-309.

8. Yurtsever, M.; Sengil, I. A. J. Hazard. Mater., 2009, 163, 58-64.

9. Soylak, M.; Elci, L.; Akkaya, Y.; Dogan, M. Anal. Lett., 2002, 35, 487-499.

10. Balarak, D.; Azarpira, H. Int. J. ChemTech. Res., 2016, 9(7), 566-573.

11. Eren, E.; Afsin, B.; Onal, Y. J. Hazard. Mater., 2009, 161, 677-85.

12. Azarpira, H.; Mahdavi, Y. Pharma. Chem.,
2016, 8(12), 61-67.

13. Balarak, D.; Azarpira, H.;Mostafapour, F. K. Pharma. Chem., 2016, 8(10), 243-247.

14. Yin, P.; Yu, Q.; Lin, Z.; Kaewsarn, P. Environ. Technol., 2001, 225, 509-614.

15. Ramesh, S.T.; Rameshbabu, N.; Gandhimathi, R. Appl. Water Sci., 2013, 3(1), 1025-1113.

16. Benguella, B. H.; Benaissa, H. Water. Res., 2002, 36, 2463-2474.

17. Kumar, U.; Bandyopadhyay, M. Bioresour. Technol., 2006, 97, 104-119.

18. Zazouli, M. A.;Mahdavi, Y.;Bazrafshan, E. J. Environ. Health. Sci. Eng., 2014, 12(66), 1-5.

19. Diyanati, R. A.; Cherati, J.Y. J. Mazandaran Univ. Med. Sci., 2013, 22(2), 58-64.

20. Rozkhash, M.; Eslami, SV. J. Plant Prot. Res., 2015, 284, 579-588.

21. Balarak, D.; Jaafari, J.;Hassani, G.;Mahdavi, Y.;Tyagi, I.; Agarwal, S.; Gupta, V. K. Colloid Interface Sci. Commun., 2015, 7, 16-19.

22. Diyanati, R. A.; Yousefi, Z.; Cherati, J. Y. J. Mazandaran Univ. Med. Sci., 2013, 22(2), 13-21.

23. Zheng, W.; L i, X. M.; Yang, Q.; Zang, G. M.; Shen, X.; Zhang, Y. J. Hazard. Mater., 2007, 147, 534-539. 
24. Ayuso, E. A.; Sanchez, G. J. Hazard. Mater., 2007, 147, 594-600.

25. Diyanati, R. A.; Yousefi, Z.; Cherati, J. Y.; Balarak, D. J. Mazandaran Univ. Med. Sci., 2013, 23, 17-23.

26. Azarpira, H.; Mahdavi, Y.; Khaleghi, O. Pharm. Lett., 2016, 8(11), 107-113.

27. Fuhrman, H. G.; Mikkelsen, P. S.; Ledin, A. Water. Res., 2007, 41, 591-602.

28. Balarak, D, Mostafapour, F. K.; Joghataei, A. Pharma. Chem., 2016, 8(8), 138-145.

29. Costodes, V. C. T.; Fauduet, H.; Porte, C.; Delacroix, A. J. Hazard. Mater., 2003, 103, 121-142.

30. Ashrafi, S. D.; Rezaei, S.; Forootanfar, H.; Mahvi, A. H.; Faramarzi, M. A. IntBiodeter. Biodegr., 2013, 85,173-181.

31. Pandey, K.; Sharma, S. K.; Sambi, S. S. Int. J. Environ. Sci. Tech., 2010, 7(2), 395-404.

32. Christoforidis, A. K.; Mitropoulos, A.C. Chem. Eng. J., 2015, 277, $334-340$.

33. Mata, Y. N.; Munoz, J. A. J. Hazard. Mater., 2009, 166, $612-618$.

34. Luo, D.; Xie, Y. F.; Tan, Z. L.; Li, X. D. J. Environ. Biol., 2012, 34, 359 - 365.

35. Balarak, D.; Azarpira, H.; Mostafapour, F. K.
Pharma. Chem., 2016, 8(10), 114-121.

36. Li, Y. H.; Di, Z. C.; Ding, J.; Wu, D. H.; Luan, Z. K.; Zhu, Y. Q. Water. Res., 2005, 39, 605-609.

37. Unlu, N.; Ersoz, M. J. Hazard. Mater., 2006, 136, 272-280.

38. Martins, B. L.; Cruz, C. C. V.; Luna, A. S.; Henriques, A. C. Biochem. Eng. J., 2006, 27, 310-314.

39. Balarak, D.; Mahdavi, Y.; Bazrafshan, E.; Mahvi, A. H. Fresenius. Environ. Bull., 2016, 25(5), 1321-30.

40. Meng, Y. T.; Zheng, Y. M.; Zhang, L. M.; He, J. Z. Environ. Pollut., 2009, 157, 2577-2583.

41. Pacheco, S.; Tapia, J.; Medina, M. R.; Rodriguez, R. J. Non-Cryst. Solids., 2006, 352, 5475-5481.

42. Inbaraj, B. S.; Sulochana, N. Ind J Chem Technol., 2006, 13, 17-23.

43. Uddin, S. M.; Azad, A. K.; Firdaus R. Orient. J. Chem., 2013, 29(2), 241-250.

44. Malviya, A.; Kaur, D. Orient. J. Chem., 2012, 28(2), 48-57.

45. Sirait, M.;Gea, S.; Bukit, N.;Siregar, N.;Sitorus, C. Orient. J. Chem., 2018, 34(4), 185-191. 